\title{
Tephrochronology in faulted Middle Pleistocene tephra layer in the Val d'Agri area (Southern Italy)
}

\author{
Giuliana D’Addezio $\left({ }^{1}\right)$, Daniel B. Karner $\left({ }^{2}\right)$, Pierfrancesco Burrato $\left({ }^{1}\right)$, Donatella Insinga $\left({ }^{4}\right)$, \\ Laura Maschio $\left({ }^{3}\right)$, Luigi Ferranti $\left({ }^{3}\right)$ and Paul R. Renne $\left({ }^{5}\right)\left({ }^{6}\right)$ \\ (1) Istituto Nazionale di Geofisica e Vulcanologia, Roma, Italy \\ (2) Department of Geology, Sonoma State University Rohnert Park, CA, U.S.A. \\ $\left(^{3}\right)$ Università degli Studi di Napoli «Federico II», Napoli, Italy \\ $\left({ }^{4}\right)$ Istituto per l'Ambiente Marino Costiero (IAMC), CNR, Napoli, Italy \\ $\left({ }^{5}\right)$ Berkeley Geochronology Center, Berkeley, CA, U.S.A. \\ $\left(^{6}\right)$ Department of Earth and Planetary Science, University of California, Berkeley, CA, U.S.A.
}

\begin{abstract}
The High Agri River Valley is a Quaternary Basin located along the hinge of the Southern Apennines fold-andthrust belt. The inner margin of the orogen has been affected by intense transtensional and normal faulting, which accompanied vigorous volcanism during the Quaternary. Marker tephra layers are distributed across the whole of Southern Italy and provide a powerful tool to constrain both the size of eruptions and the regional activity of extensional faults controlling basin evolution. Paleoseismological trenching within the Monti della Maddalena range, that borders the Agri River Valley to the south-west, has exposed a faulted stratigraphic sequence and recovered a $10 \mathrm{~cm}$ thick tephra layer involved in deformation. This is the first tephra horizon recognized in the high Agri Valley, which, based on the stratigraphic study of the trench, lies in a primary position. 40Ar/39Ar dating constrain its age to $266 \mathrm{ka}$ and provide an important marker for the Middle Pleistocene tephrochronology of the region. Together with dating, geochemical analysis suggests a possible volcanic source in the Campanian region.
\end{abstract}

Key words tephra layer $-{ }^{40} \mathrm{Ar} /{ }^{39} \mathrm{Ar}$ dating - Southern Italy

\section{Introduction}

The high valley of the Agri River (High Agri Valley, HAV in fig. 1) is a Quaternary tectonic depression located along the axis of the Neogene-Quaternary Southern Apennines fold-andthrust belt (fig. 2). The HAV formed during Pleistocene-Holocene time in relation to the

Mailing address: Dr. Giuliana D'Addezio, Istituto Nazionale di Geofisica e Vulcanologia, Via di Vigna Murata 605, 00143 Roma, Italy; e-mail: daddezio@ingv.it eastward extension associated to the opening of the Tyrrhenian Sea (Malinverno and Ryan, 1986; Hippolyte et al., 1995).

Mesostructural and geomorphological investigations along the Monti della Maddalena range to the west of the HAV have identified a $3.5 \mathrm{~m}$ high scarp which intercepts unconsolidated sediments, and this geomorphic feature likely represents the surface expression of a hidden seismogenic fault (Maschio et al., 2005). In fact, this area has been struck by destructive earthquakes, including the December 16, 1857 $I_{\max }=\mathrm{XI}, M e=7$ event (fig. 2; Working Group CPTI, 2004). Paleoseismological investigations have been performed along the easternmost portion of the scarp to identify evidence for recent slip. As a means to constrain timing of de- 


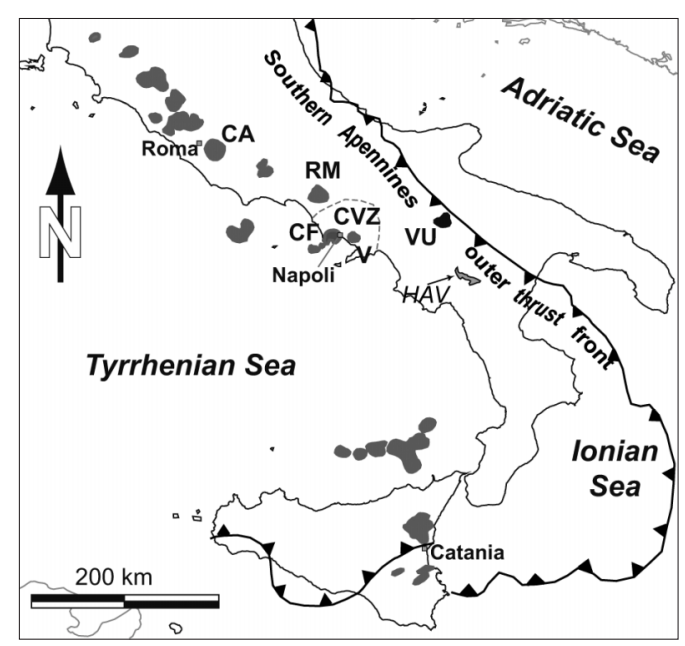

Fig. 1. Location map of the High Agri Valley (HAV) and distribution of the main volcanic districts along the central-southern Italy (dark areas). Key to abbreviations (from north to south): CA - Colli Albani; RM Roccamonfina; CVZ - Campanian Volcanic Zone (within dashed line); CF - Campi Flegrei; V - Vesuvius; VU - Mt. Vulture; HAV - High Agri Valley. formation, radiocarbon dating has been performed on faulted paleosols together with ${ }^{40} \mathrm{Ar} /{ }^{39} \mathrm{Ar}$ dating on sanidine samples from a recognized tephra horizon outcropping in the trench sequence.

Other tephra layers of Middle Pleistocene age from Southern Apennines have been previously studied (e.g., Caggianelli et al., 1992; Ciaranfi et al., 1996; Bonadonna et al., 1998; Karner et al., 1999). This paper documents the first tephra layer found within the High Agri Valley, and as such helps place the valley in tectonic context with other basins found within the Southern Apennines. As a matter of fact, distal tephra layers are powerful tools for regional lithostratigraphic correlations and can be used to constrain the timing of regional tectonic-sedimentary processes. The geochemical signatures from different volcanic provinces make it possible to discriminate among sources for these distal tephra layers, although this geochemical characterization is not yet sufficiently complete to unambiguously correlate individual horizons to volcanic sources in Southern Italy.

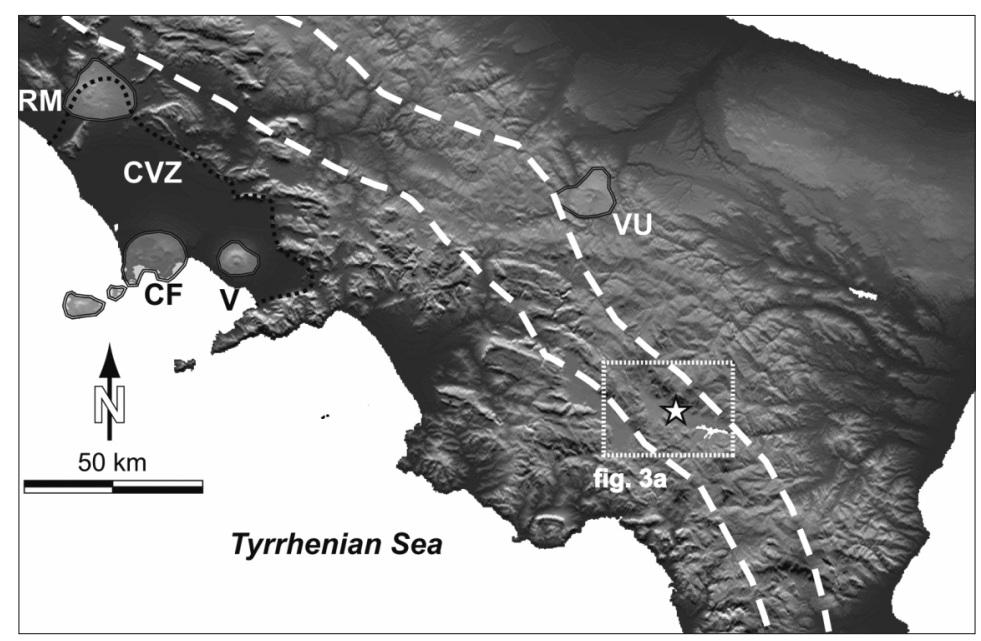

Fig. 2. Location of the HAV within the Southern Italy seismic belt. The star locate the epicentral area of the $M$ 7.01857 earthquake (Working Group CPTI, 2004). The main volcanic districts closer to the HAV are highlighted (same abbreviations as in fig. 1). Note that besides the Mt. Vulture (VU), they all are located along the inner Tyrrhenian margin of the Southern Apennine fold-and-thrust belt. The dashed white lines indicate the Southern Italy seismic belt (i.e. the area where the maximum seismic moment is released). Dotted line indicate the distribution of CVZ products (Rolandi et al., 2003). 
Considering the importance of documenting tephrochronology histories in the Southern Apennines to constrain the timing of basin tectonism, we present a study of the tephra layer recovered in the trench. We suggest possible sources for this layer, but acknowledge that more information is needed before unambiguously correlate it with its eruptive source.

\section{Volcanism of central-southern Italy}

During the Pliocene-Pleistocene extensional tectonics, volcanic activity occurred along the Eastern Tyrrhenian margin, at the intersection between NW-SE- and NE-SW-trending faults (Beccaluva et al., 1989). The NW-trending, Quaternary to Recent volcanic belt was characterized by explosive activity which produced eruption columns which were dispersed downwind. The related distal tephra layers, which can be found interbedded within continental and marine deposits, represent distinctive chronostratigrahic markers in the successions and provide a means to study relationships among volcanism, regional tectonic, sedimentary and paleoclimatology processes.

The volcanic districts of central-southern Italy are grouped into the Roman Comagmatic Province (RCP; Washington, 1906) which includes the eruptive centers in Southern Tuscany and Latium, such as Sabatini, Vico, Vulsini, Colli Albani, Ernici and Roccamonfina districts, and the Campanian Volcanic Zone (the Campi Flegrei-Procida Island, Ischia Island and Somma-Vesuvio complex) (figs. 1 and 2). Mt. Vulture is the only volcanic complex located east of the Apennine Chain (fig. 2).

Volcanic products of the RCP range in composition from shoshonitic basalts to trachyphonolites (potassic series) and from basanites and leucitites to phonolites (ultrapotassic series) (Appleton, 1972). At Roccamonfina volcano, both series are represented.

The Roccamonfina, the Campanian volcanic centers and the Mt. Vulture volcano, located at about 200, 150 and $80 \mathrm{~km}$, respectively, from the HAV trench site, represent the most proximal areas (fig. 2). Large volumes of pyroclastics were erupted from all of these districts.
Roccamonfina's deposits have a distribution limited mainly to the northern sectors of the Campanian region while volcanoclastic products related to the youngest activity phase of the Colli Albani district (Peperino Albano Ignimbrite, $30 \mathrm{ka}$; Giordano et al., 2002) have been recognized in the lacustrine sediment record of Lago Grande di Monticchio inside the Mt. Vulture crater (Wulf et al., 2004). High magnitude events took place, particularly in the Campanian region during the Pleistocene as testified by the occurrence of several tephra layers in the stratigraphic record of the Tyrrhenian and Eastern Mediterranean Sea (Keller et al., 1978; Paterne et al., 1986, 1988; Narcisi and Vezzoli, 1999; Rolandi et al., 2003).

In order to better constrain a possible source area for the sampled tephra, we briefly present the principal periods of activity and the main petrologic and volcanologic features of these three volcanic areas.

\subsection{Campanian volcanic zone}

The Campanian volcanoes are the most recent and still active volcanic areas of the RCP. The Campi Flegrei-Procida Island and Ischia Island products belong to the potassic series and more than $90 \%$ of these is constituted by evolved rocks (trachytes and phonolitic trachytes; Di Girolamo et al., 1984; Rosi and Sbrana, 1987). Sanidine is the most abundant phenocryst and microphenocryst phase.

The Vesuvius products can be grouped into the high potassium series (HKS; Appleton, 1972) and they are represented by leucite-bearing basanites to phonolites. Less undersaturated potassic rocks were erupted by Somma-Vesuvius during the first phase of its activity $>17 \mathrm{ka}$ (Santacroce, 1987).

The beginning of activity at Campi Flegrei and Somma-Vesuvio complex has been dated at about $>60 \mathrm{ka}$ and $400 \mathrm{ka}$, respectively (Brocchini et al., 2001; Pappalardo et al., 2002). Ages older than $150 \mathrm{ka}$ have been found in the lowest pyroclastic products of Ischia Island (Poli et al., 1987).

Ancient explosive activity in the Campanian Volcanic Zone seems to be testified by several 
trachytic ignimbrites dated at $205 \mathrm{ka}, 184 \mathrm{ka}$ and 157 ka (De Vivo et al., 2001). Furthermore, an experiment carried out on a xenocryst yielded an age of $315 \mathrm{ka}$ (De Vivo et al., 2001). The older ignimbrite deposits where dated at 290 to $246 \mathrm{ka}$ (Rolandi et al., 2003). These eruptions largely predate the Campanian Ignimbrite (37.1 ka, Deino et al., 1992; 39 ka, De Vivo et al., 2001) which represents one of the largest event in the Mediterranean region during the last $200 \mathrm{ka}$.

\subsection{Roccamonfina}

The Roccamonfina strato-volcano is formed mostly by leucite-bearing, High-K Series (HKS) lavas and tephra. Low-K Series (LKS; Appleton, 1972) products are often associated with HKS deposits in several parasitic centers. The main cone of the volcano started to form during the 549-374 ka BP leucite-bearing HKS Stage I while during the 317-96 ka BP leucite-free LKS Stage II the parasitic vents formed. An intermediate phase with concurrent HKS-LKS products, occurred between 376-323 ka BP (Giannetti and De Casa, 2000; Giannetti, 2001). During this period a large ignimbrite formation $(385-335 \mathrm{ka}$ BP, Brown Leucitic Tuff; Luhr and Giannetti, 1987) was erupted after the collapse of the central and northern calderas. A sequence of trachytic pyroclastic flows and surge deposits with very minor Plinian pumice fall-outs, namely White Trachytic Tuff (WTT) (Giannetti and Luhr, 1983), erupted over an interval of nearly 100000 years (317 ka-230 ka BP) during small-volume (about $1 \mathrm{~km}^{3}$ for each member) explosive eruptions (Giannetti and De Casa, 2000).

\subsection{Mt. Vulture}

The Mt. Vulture strato-volcano is the easternmost district of the Roman Magmatic Province and it is located at the western border of the Adriatic-Bradanic foredeep (La Volpe et al., 1984). This peculiar structural setting accompanies a distinctive composition of magmas, which are characterized by both $\mathrm{K}$ and $\mathrm{Na}$ enrichments, together with a significant presence of extremely silica-under saturated melilite-bearing products
(Melluso et al., 1996). The eruptive history of the Mt. Vulture has been divided into three main phases which cover a time-span ranging from 800 ka to $130 \mathrm{ka}$ (740 ka, 600-500 ka, 132-133 ka; Brocchini et al., 1994). During the initial phase of volcanic activity (Laurenzi et al., 1993), trachyphonolitic pyroclastic falls and flows with lava blocks and domes were erupted. The second (Broc-chini et al., 1994) and third (Guest et al., 1988; Stoppa and Principe, 1997) eruptive phases were characterized by pyroclastic and lava flow deposits of a generally mafic composition (tephrite, phonotephrite, basanite; Beccaluva et al., 2002), with some carbonatitic lapilli tuffs interbedded within the most recent deposits of the Monticchio tephra (Stoppa and Woolley, 1997). Phreatomagmatic activity, typically found in the younger period, formed the Monticchio lakes.

\section{Tectonic and geologic setting of the Val D'Agri}

The High Agri Valley is a Quaternary tectonic depression located in the axial portion of the Southern Apennines (fig. 2). Starting from the Late Miocene, back-arc extension related to the opening of the Tyrrhenian Basin affected the inner portion of the chain, and migrated eastward at the rear of the compressional fronts (Malinverno and Ryan, 1986; Hippolyte et al., 1995). During Early Pleistocene, strike-slip faulting affected the chain, and formed intermontane basins, such as the High Agri Valley and the Vallo di Diano (fig. 3a; e.g., Karner et al., 1999; Giano et al., 2000). Starting from Middle Pleistocene, high-angle normal faults controlled formation of accommodation space and sedimentation within the basins (Cinque et al., 1993; Hippolyte et al., 1994). At the same time, to the west, crustal thinning led to volcanism along the Tyrrhenian margin (e.g., Barberi et al., 1994).

In the HAV, recent to ongoing extension is considered to be accommodated by a newly formed NE-dipping fault system located within the Monti della Maddalena range to the west of the valley (MMFS in fig. 3a, Maschio et al., 2005).

Morphologically, the HAV follows an arcuate NNW- to WNW-trend (fig. 3a). The basin is 

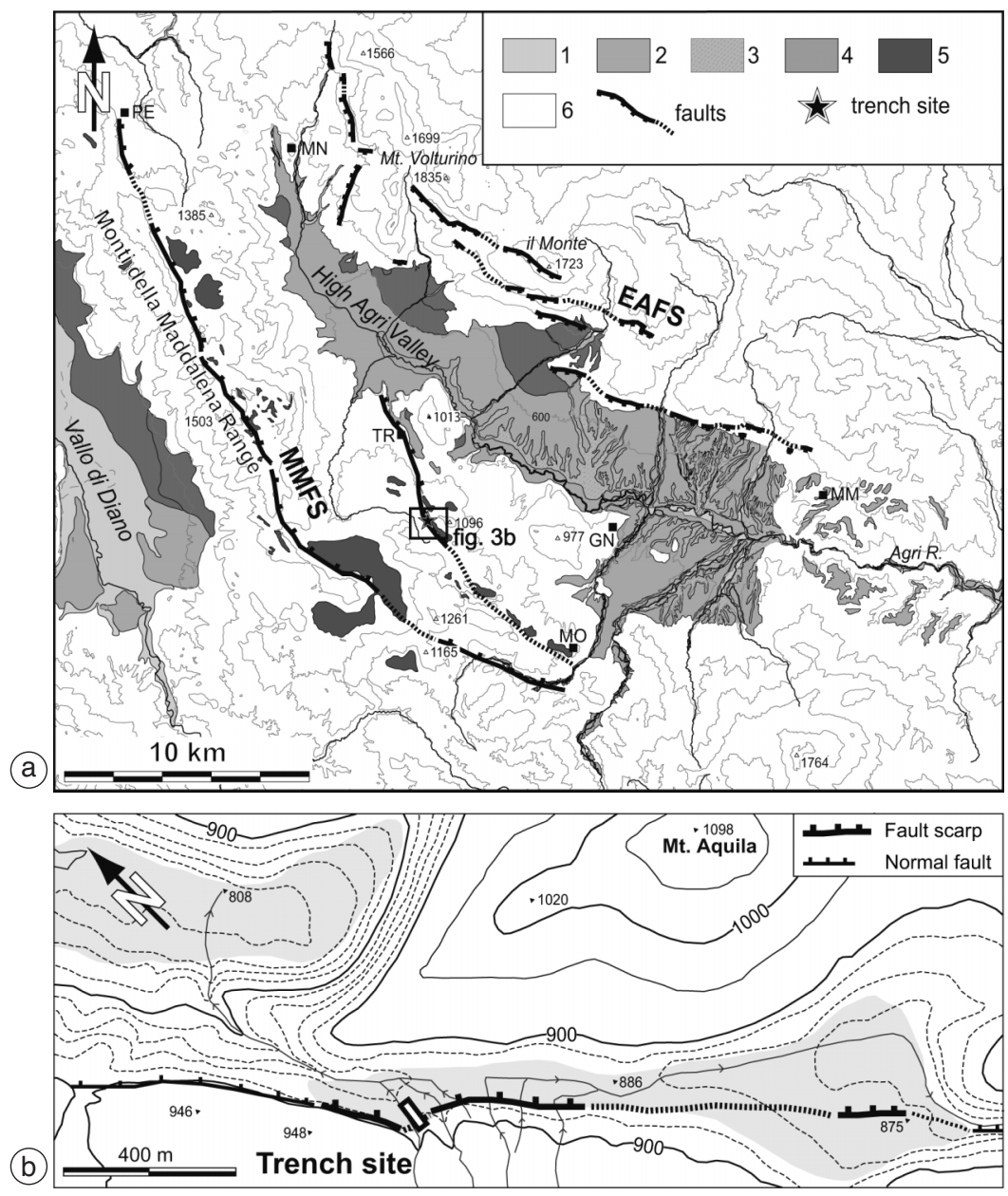

Fig. 3a,b. a) Morphotectonic map of the High Agri Valley, showing the main Quaternary morphological features, recent fault systems (traces of the Monti della Maddalena Fault System- MMFS and of the East Agri Fault System-EAFS after Maschio et al., 2005), drainage network and topography (contours every $100 \mathrm{~m}$ ). Key to symbols: 1 - Holocene alluvial plain; 2 - Middle Pleistocene alluvial deposits; 3 - middle Pleistocene «Complesso Val d'Agri»; 4 - Pleistocene-Holocene slope deposits and alluvial fans; 5 - Quaternary intra-mountane basins filled with lacustrine and colluvial deposits; 6 - Pre-Quaternary bedrock. Towns: MN, Marsico Nuovo; TR, Tramutola; GN, Grumento Nova; MO, Moliterno; MM, Montemurro. b) Detail of the eastern branch of the Monti della Maddalena Fault System (MMFS, Maschio et al., 2005). Along this $2 \mathrm{~km}-\mathrm{long}$ section, young colluvial deposits are displaced by 2-3 m high normal fault scarps. The paleoseismological trench has been dug across an E-W-trending relay connecting two left-stepping an-echelon fault scarps. Recent basins filled with alluvial and wash deposits are aligned along the fault, and are highlighted in light-gray.

axially drained to the southeast by the Agri River, which forms in an up-stream section a wide active alluvial plain deeply incised towards the basin threshold. Close to the basin threshold, three orders of terraces are entrenched into the Middle-Upper Pleistocene age sedimentary sequence (fig. 3a). Numerous small perched Quaternary basins, filled with lacustrine and slope 
deposits, align along the topographic crest of the Monti della Maddalena range, and may be considered the surface expression of the active tectonic fault system (Maschio et al., 2005; fig. 3a).

\section{Stratigraphy sequence at the trench site}

A $40 \mathrm{~m}$-long, N-S trending trench was excavated on an E-W bend of the $2 \mathrm{~km}$-long, NW-SE trending main fault scarp (MMFS in fig. 3a), where it intersects young unconsolidated deposits (fig. 3b; Maschio et al., 2005) (Coordinates: Lat 15.802, Long 40.289). Paleoseismological techniques principally consist of identify- ing deformation in the surface emergence of a seismogenic fault. In this study, the detailed reconstruction of the stratigraphy sequence exposed along the 3 to $4 \mathrm{~m}$-high vertical walls of the trench, has distinguished some of the geological records of past large earthquakes which have affected the High Agri Valley. The trench walls were logged in detail to evaluate structural and stratigraphic relationships exposed by the excavation. The stratigraphy has shown a sequence of young colluvial soils rich in volcaniclastic materials, downfaulted against the bedrock composed of Mesozoic argillite and limestone. We therefore detail part of the more complete stratigraphic sequence to which the deformed ash layer be-

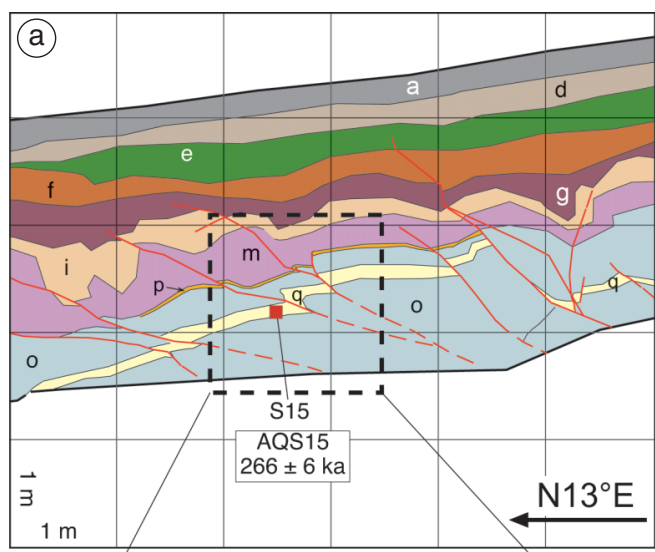

(b)

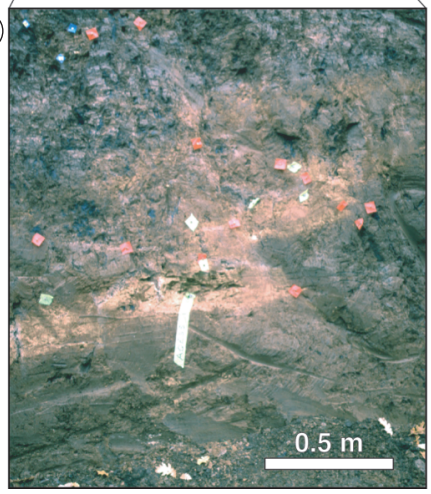

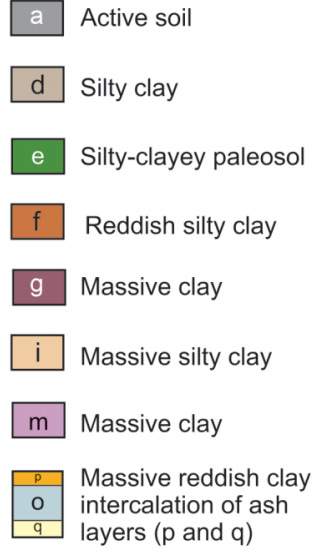

layers ( $p$ and $q$ )

Fig. 4a,b. a) Schematic log of the stratigraphy exposed in a 6 m-long section of the eastern trench wall; and b) photo showing a detail of the volcanic pumice layer studied in this paper. The pumice layer q (the lighter coloured deposit in the photo) is deformed and displaced by secondary reverse and thrust faults, suggesting a local contractional component formed at the toe of a principal normal fault zone. 
longs (fig. 4a,b). From the top to the bottom, the trench stratigraphy consists of:

a - fine-grained light brown active soil, with bioturbation and roots approaching the surface. Lower boundary gradually in $\mathrm{d}$;

$\mathrm{d}$ - fine-grained reddish-brown silty clay; leosol;

e - fine-grained dark brown silty-clayey pa-

f - reddish-brown silty clay with light brown laminations and weathered pumice and sparse very fine calcareous-mudstone (bedrock) fragments;

$\mathrm{g}$ - massive brown clay with weathered pumice and sparse fine calcareous-mudstone (bedrock) fragments. At the base chips of unit i;

i - massive light reddish-brown clay with fine weathered pumice and sparse minerals;

$\mathrm{m}$ - dark reddish-brown vacuolar clay with conchoidal fracture and with diffused manganese concretions mainly at the top of the unit, sparse minerals and very fine sub-angular calcareous mudstone (bedrock) fragments;

o - massive reddish clay with diffused manganese concretions and very fine calcareous mudstone (bedrock) fragments; the unit present intercalation of pumice layers;

$\mathrm{p}$ - very thin (up to $3 \mathrm{~cm}$ ) and localized ( $>4$ $\mathrm{m}$-long) orange-brown ash bed composed by altered pumice; and

$\mathrm{q}$ - light yellow pumice layer formed by poorly welded, medium coarse pumice, locally altered, with visible mineral grains. Maximum thickness $10 \mathrm{~cm}$.

Several samples were collected from the stratigraphic sequence to provide time constraints on the depositional and deformational history recorded in the trench, which, on a preliminary analysis, reveals at least three events of surface faulting. In the following, we detail on the geochemical and radiometric characterization of tephra layer $q$ sampled close to the bottom of the trench (fig. 4a,b).

\section{Analytical methods}

\subsection{Petrochemical analysis}

Major and trace element analysis of pumice from tephra $q$ was carried out using a wave-
Table I. Major oxide (wt\%) and trace element (ppm) contents for sample $F 1$, representative of tephra $q$. Water-free analysis.

\begin{tabular}{cr}
\hline \hline Sample & \multicolumn{1}{c}{$F 1$} \\
\hline $\mathrm{SiO}_{2}$ & 56.89 \\
$\mathrm{TiO}_{2}$ & 1.11 \\
$\mathrm{Al}_{2} \mathrm{O}_{3}$ & 26.68 \\
$\mathrm{Fe}_{2} \mathrm{O}_{3}$ & 8.80 \\
$\mathrm{MnO}$ & 0.29 \\
$\mathrm{MgO}$ & 1.78 \\
$\mathrm{CaO}$ & 1.09 \\
$\mathrm{Na}_{2} \mathrm{O}$ & 0.15 \\
$\mathrm{~K}_{2} \mathrm{O}$ & 2.91 \\
$\mathrm{P}_{2} \mathrm{O}_{5}$ & 0.30 \\
$\mathrm{Sum}$ & 100.00 \\
$\mathrm{Zn}$ & 153 \\
$\mathrm{Ni}$ & 45 \\
$\mathrm{Rb}$ & 161 \\
$\mathrm{Sr}$ & 192 \\
$\mathrm{Y}$ & 43 \\
$\mathrm{Zr}$ & 679 \\
$\mathrm{Nb}$ & 82 \\
$\mathrm{Sc}$ & 9 \\
$\mathrm{~V}$ & 152 \\
$\mathrm{Cr}$ & 69 \\
$\mathrm{Ba}$ & 1046 \\
$\mathrm{Nb} / \mathrm{Y}$ & 1.9 \\
$\mathrm{Zr} / \mathrm{TiO}$ & 0.10 \\
& \\
&
\end{tabular}

length-dispersive $X$-Ray fluorescence spectrometer (Philips PW 1400) at CISAG, University of Naples. Petrochemical composition was obtained on pressed powder pellets and the data were corrected according to procedures described in Melluso et al. (1995) (table I). Calibration curves were obtained using 35 international standards. Precision is better than $5 \%$ for major elements (excluding $\mathrm{P}_{2} \mathrm{O}_{5}$ ) and for $\mathrm{Rb}, \mathrm{Sr}, \mathrm{Y}, \mathrm{Zr}, \mathrm{Nb}, \mathrm{Zn}$ and $\mathrm{V}$, and better than $10 \%$ for the remaining trace elements excluding Sc, for which precision is closer to the XRF detection limits.

\section{2. ${ }^{40} \mathrm{Ar} /{ }^{39} \mathrm{Ar}$ dating}

${ }^{40} \mathrm{Ar} /{ }^{39} \mathrm{Ar}$ age analysis was performed at the Berkeley Geochronology Center using facilities 
and procedures similar to those described in Karner and Renne (1998). A sample of tephra $q$ was wet-sieved, and then the residue was dried. Nearly, all the residue consisted of equidimensional, optically transparent sanidine, with no evidence of reworking. Sanidine phenocrysts, approximately $1 \mathrm{~mm}$ in diameter, have been hand picked from the residue. Twenty crystals were selected for clarity under the binocular microscope and cleaned in an ultrasonic bath of $7 \%$ HF solution for approximately one minute to remove surface alteration and to reduce atmospheric contamination. The crystals were placed in an aluminum disk along with the neutron fluence monitor (standard) Alder Creek Tuff sanidine (1.194 Ma; Renne et al., 1998) and irradiated at the TRIGA reactor at Oregon State University for approximately $30 \mathrm{~min}$. The irradiation was cadmium shielded to minimize the ${ }^{40} \mathrm{~K}(n, p){ }^{40} \mathrm{Ar}$ reaction by reducing the thermal neutron fluence (Tetley et al., 1980).

A fully automated microextraction-mass spectrometer system was used for the ${ }^{40} \mathrm{Ar} /{ }^{39} \mathrm{Ar}$ analysis. MAP1 includes a $\mathrm{CO}_{2}$ laser for sample heating, and a Mass Analyzer Products (MAP) $21590^{\circ}$ sector extended-geometry mass spectrometer. Because there are relatively small crystals associated with this distal ash-fall horizon, it was necessary to analyze multiple crystals at once to increase the Ar signal to significantly above background level. Three or four crystals were placed into each of six pits in a copper disk, and then placed into the microextraction system. Fusion of each pit has been separately done, the released gases scrubbed of reactive species using C-50 getters and a cryogenic condensation trap. The released gases were exposed to the getters for

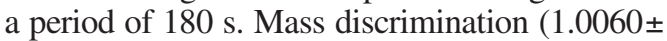
$\pm 0.0022 / \mathrm{amu}$, applied as a power law correction) was monitored by analyzing air pipettes throughout the experiment. Background corrections made from full system blanks were run between every three sample analyses.

\section{Results}

\subsection{Chemical classification of tephra $\mathrm{q}$}

The major element composition clearly indicates a pervasive alteration of tephra $q$ as suggested, for instance, by the high content of $\mathrm{Al}_{2} \mathrm{O}_{3}(23.4 \%)$, the very low content of $\mathrm{Na}_{2} \mathrm{O}$ $(0.15 \%)$, and $\mathrm{K}_{2} \mathrm{O}(2.91 \%)$ (table I). To better classify the analysed sample, elements such as $\mathrm{Zr}$, Ti, $\mathrm{Nb}$ and $\mathrm{Y}$ were used, because of their rel-
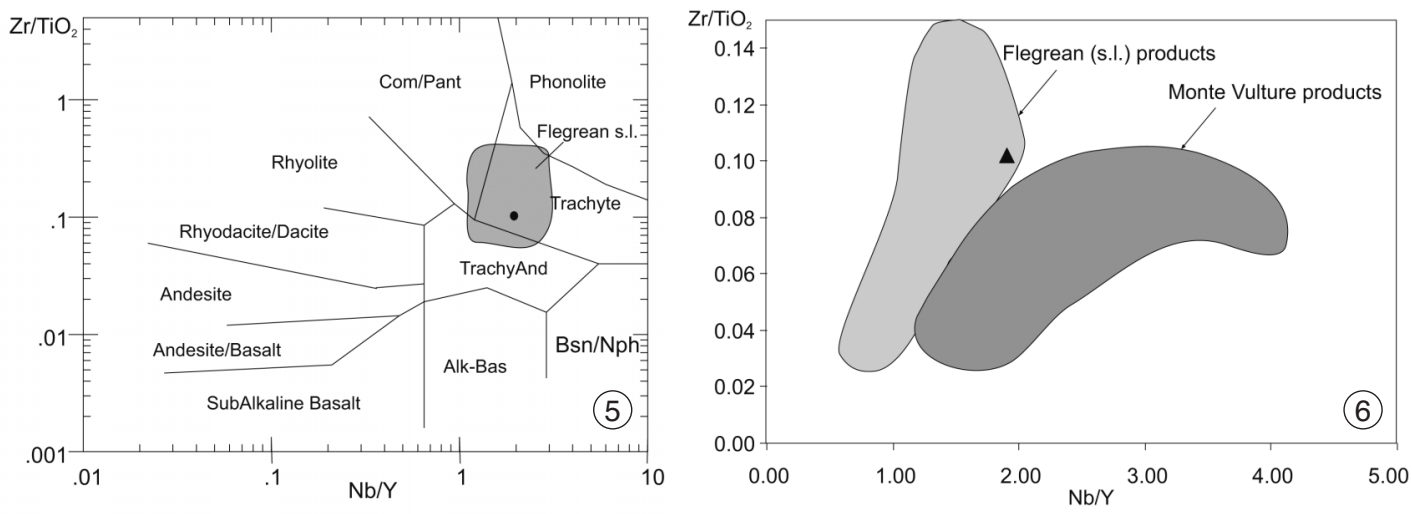

Fig. 5. Classification of sample $F 1$ (black dot), representative of tephra $q$, according to Winchester and Floyd (1977). Composition of flegrean products is also shown for comparison (data from Pappalardo et al., 2002).

Fig. 6. Diagram $\mathrm{Nb} / \mathrm{Y}$ versus $\mathrm{Zr} / \mathrm{TiO}_{2}$ showing the geochemical affinity of sample $F 1$ (black triangle) with the Flegrean products. Data from Pappalardo et al. (2002) for the Flegrean products and from Beccaluva et al. (2002) for the Monte Vulture products. 
atively immobile behavior during processes of argillization. As a result, tephra $q$ plots within the field of trachytic volcanics (figs. 5 and 6) and is quite in agreement with the average composition of Flegrei (s.1.) products (figs. 5 and 6).

\subsection{Ar/Ar age of tephra}

The multiple-crystal total-fusion ages are presented for each of the six separate pits that contained sanidine from tephra $q$ (table II). Ages are reported with $\pm 1 \sigma$ analytical precision. The ages for all the samples, except sample 3316103 , are statistically indistinguishable at around $260 \mathrm{ka}$. Sample 33161-03 contained three nearly equidimensional crystals, the total fusion age of which is $366.8 \pm 7.6 \mathrm{ka}$, nearly $100 \mathrm{kyr}$ older than the other five multiple-crystal total-fusion ages. This older age for 33161-03 is probably the result of one xenocryst grain being mixed with two crystals, whose ages are consistent with those crystals from the other sample pits. This suggests an approximate age of $~ 500-600$ ka for the xenocryst, but we caution that this is a gross estimate based on the assumption that each of the three crystals in this pit yielded a similar amount of Ar gas. This assumption may not have been true. Regardless of the age of the xenocryst, sample 33161-03 was eliminated from our estimate of the eruption age of the studied ash horizon. In order to estimate the eruption age of this pumice layer, we have calculated the error-weighted mean ${ }^{40} \mathrm{Ar} /{ }^{39} \mathrm{Ar}$ ratio from the five other samples (see Renne et al., 1996). Based on this error-weighted mean ${ }^{40} \mathrm{Ar} /{ }^{39} \mathrm{Ar} \mathrm{ra}-$ tio (see table II), we estimate the eruption age for the Val D'Agri pumice layer to be 266.1 $( \pm 4.9) \mathrm{ka}( \pm 1 \sigma)$. We note that the homogeneity of the Val D'Agri pumice, with probably 19 of the 20 sanidine crystals analyzed being the same age, indicates that this volcanic horizon is probably a primary (not reworked) ash horizon. Thus, its position within the Val D'Agri sedimentary succession might be considered a reliable chronostratigraphic marker.

\section{Discussion and conclusions}

A paleoseismological trench dug on a fault scarp with the intent to investigate the past seismogenic activity of the MMFS exposed a Late Pleistocene-Holocene colluvial succession which includes two distinct tephra layers namely $p$ and $q$ (fig. 4a,b). In particular, the $10 \mathrm{~cm}$ thick tephra $q$ is represented by pumice which was petrochemically analysed in terms of major and trace element content, and yielded sanidine crystals suitable for ${ }^{40} \mathrm{Ar} /{ }^{39} \mathrm{Ar}$ dating.

Table II. ${ }^{40} \mathrm{Ar} /{ }^{39} \mathrm{Ar}$ dating for the studied pumice layer.

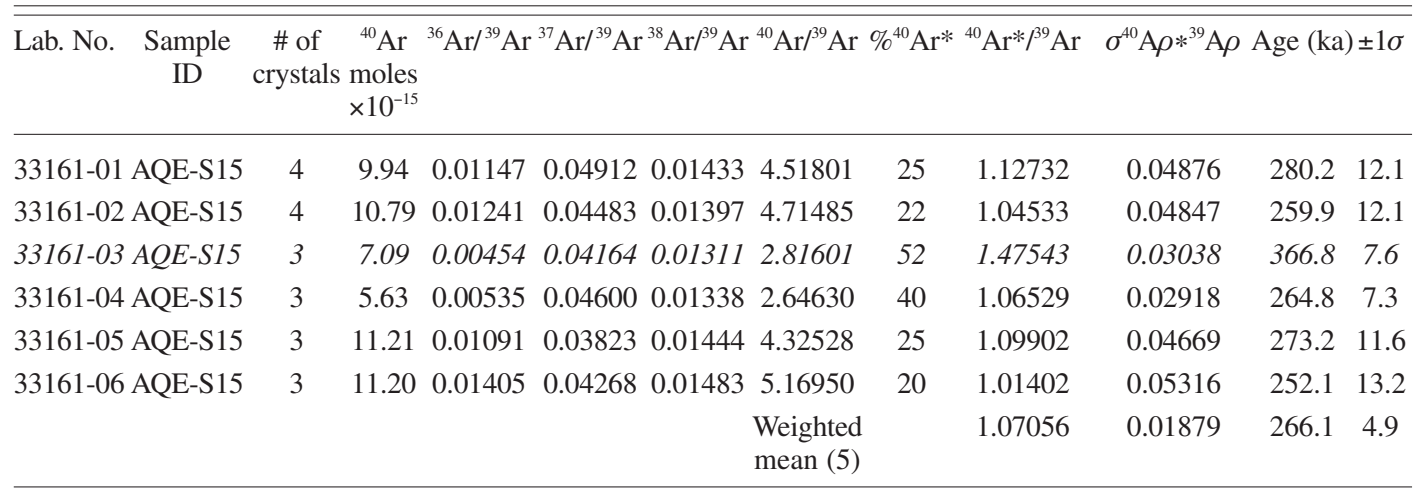

Notes: BGC Irradiation 262DK-B; J $=1.3780( \pm 0.0025) \times 10^{-4}$; Mass Discrimination $=1.0060 \pm 0.0022$. Sample in italics yielded an age that was not statistically consistent with the remaining samples, and is not included in the errorweighted mean calculation. MSWD = Mean Square Weighted Deviation. 
Tephra $q$ is characterized by a trachytic composition and the ${ }^{40} \mathrm{Ar} /{ }^{39} \mathrm{Ar}$ dating provides an age of $266 \mathrm{ka}$ for this layer.

These results and the present knowledge on the volcanic history of Southern Italy do not allow a definitive identification of the source area for the studied pumice level. In the adjacent Vallo di Diano (fig. 3a), where a sequence of tephra layers have recently been studied, the recorded eruptive period spans the approximate time interval 630-550 ka (Karner et al., 1999), preventing a possible correlation with the HAV succession. However, several considerations can be made:

a) The geochemical features and age of tephra $q$, exclude a correlation with Mt. Vulture (fig. 6), that represents the nearest volcanic area to the HAV trench site. This vent erupted trachytic products only at the beginning of its activity (740 ka; Laurenzi et al., 1993) and the chronostratigraphic reconstruction of volcanic events is not in agreement with the age of 266 ka for tephra $q$ : no activity is reported, in fact, in the time-span ranging from $500 \mathrm{ka}$ to $132 \mathrm{ka}$.

b) The Roccamonfina volcano was highly active between 317 and 230 ka during which the White Trachytic Tuff (WTT) was erupted. However, the correlation of tephra $q$ with this event appears to be difficult because the thickness $(10 \mathrm{~cm})$ and size (medium-coarse) of the studied pumice are not consistent with the small volume and the minor plinian fall-out of WTT members outcropping at about $200 \mathrm{~km}$ of distance from Val D'Agri trench site.

c) On the basis of geochemical affinities, tephra $q$ seems to be a typical product of the Campanian Volcanic Zone (Flegrei s.l.) (figs. 5 and 6; table I) whose products have been found up to $900 \mathrm{~km}$ to the south. The Campi FlegreiProcida Island, Ischia and Somma-Vesuvius activities are too recent to be genetically linked to tephra $q$. A proposal might be advanced on the basis of ancient trachytes ignimbrite deposits related to the Campanian Volcanic Zone dated by ${ }^{40} \mathrm{Ar} /{ }^{39} \mathrm{Ar}$ method at $205 \mathrm{ka}, 184 \mathrm{ka}$ and 157 ka, (De Vivo et al., 2001) and 290 to $246 \mathrm{ka}$ (Rolandi et al., 2003). These data give evidence of an older and previously unknown explosive activity in the Campanian region, which consequently extends the volcanic history of this region by over $200 \mathrm{ka}$.
In the latter case, similar coeval products are expected to cover a wide area and the occurrence of the tephra $q$, interbedded within the HAV succession, may represent important information for chronostratigraphic reconstruction of volcanic activity in Southern Italy during the Pleistocene.

\section{Acknowledgements}

We are grateful to D. Pantosti for her support and suggestions, to P.M. De Martini, S. Pucci and P. Vannoli for the help in the field work and to Prof. Vincenzo Morra for the XRF analysis performed at CISAG (University of Naples). Prof. Serafina Carbone and an anonymous referee are acknowledged for revising the manuscript and for constructive suggestions. We also thank S. Wulf for the helpful review of an earlier version of the manuscript. Financial support was provided by the INGV.

\section{REFERENCES}

Appleton, J.D. (1972): Petrogenesis of potassium-rich lavas from the Roccamonfina volcano, Roman region, Italy, J. Petrol., 13 (3), 425-456.

Barberi, F., G. Buonasorte, R. Cioni, A. Fiordelisi, L. Foresi, S. IACCARino, M.A. Laurenzi, A. Sbrana, A. VERNIA and I.M. VILlA (1994): Plio-Pleistocene geological evolution of the geothermal of Tuscany and Latium, Memorie Descrittive della Carta Geologica d'Italia, 49, 63-109.

Beccaluva, L., P. Brotzu, G. Macciotta, L. Morbidelli, G. SERri and G. Traversa (1989): Cenozoic tectonomagmatic evolution and inferred mantle sources in the Sardo-Tyrrhenian area, in The Lithosphere in Italy. Advances in Earth Science Research, edited by A. BORIAni, M. Bonafede, G.B. Piccardo and G.B. VAi (It. Nat. Comm. Int. Lith. Progr., Mid-term Conf., Atti Conv. Lincei), 80, 229-248.

Beccaluva, L., M. Coltorti, P. Di Girolamo, L. MelluSo, L. Milani, V. Morra and F. Siena (2002): Petrogenesis and evolution of Mt. Vulture alkaline volcanism (Southern Italy), Mineral. Petrol., 74, 277-297.

Bonadonna, F.P., D. Brocchini, M.A. Laurenzi, C. PrinCIPE and G. FERrARA (1998): Stratigraphical and chronological correlations between Monte Vulture volcanics and sedimentary deposits of the Venosa Basin, Quatern. Int., 47/48, 87-96.

Brocchini, D., L. La Volpe, M.A. Laurenzi and C. PrinCIPE (1994): Storia evolutiva del Monte Vulture, Plinius, 12, 22-25.

Brocchini, D., C. Principe, D. Castratori, M.A. Lauren- 
ZI and L. GoRla (2001): Quaternary evolution of the southern sector of the Campanian Plain and early Somma-Vesuvius activity: insights from Trecase 1 well, Mineral. Petrol., 73, 67-91.

Caggianelli, A., P. Dellino and L. Sabato (1992): Depositi lacustri infrapleistocenici con intercalazioni vulcanoclastiche (Bacino di Sant'Arcangelo, Basilicata), Il Quaternario, 5 (1), 123-132.

Ciaranfi, N., M. Marino, L. SABATo, A. D'Alessandro and R. DE RosA (1996): Studio geologico stratigrafico di una successione infra e mesopleistocenica nella parte sudoccidentale della Fossa Bradanica (Montalbano Jonico, Basilicata), Boll. Soc. Geol. It., 115, 371-391.

Cinque, A., E. Patacca, P. SCANDONE and M. Tozzi (1993): Quaternary kinematic evolution of the Southern Apennines. Relationships between surface geological features and deep lithospheric structures, Ann. Geofis., XXXVI (2), 249-260.

Deino, A., G. CurTis and M. Rosi (1992): ${ }^{40} \mathrm{Ar} /{ }^{39} \mathrm{Ar}$ dating of the Campanian Ignimbrite, Campanian region, Italy, in 29th International Geological Congress, August 24September 3, Kyoto, 3, 633 (Abstracts).

De Vivo, B., G. Rolandi, P.B. Gans, A. Calvert, W.A. Bohrson, F.J. Spera and H.E. Belkin (2001): New constraints on the pyroclastic eruptive history of the Campanian volcanic Plain (Italy), Mineral. Petrol., 73, 47-65.

Di Girolamo, P., M.R. Ghiara, L. Lirer, R. Munno, G. Rolandi and D. Stanzione (1984): Vulcanologia e petrologia dei Campi Flegrei, Boll. Soc. Geol. It., 103, 349-413.

GianNETTI, B. (2001): Origin of the calderas and evolution of Roccamonfina volcano (Roman region), J. Volcanol. Geotherm. Res., 106, 301-319.

GiannetTi, B. and G. DE CASA (2000): Stratigraphy, chronology, and sedimontology of the White Trachytic Tuff, Roccamonfina volcano, Italy, J. Volcanol. Geotherm. Res., 96, 243-295.

Giannetti, B. and J.F. LuHR (1983): The white trachytic tuff of Roccamonfina volcano (Roman region, Italy), Contrib. Mineral. Petrol., 84, 235-252.

Giano, S.I., L. Maschio, M. Alessio, L. Ferranti, S. ImPROTA and M. SCHIATTARELLA (2000): Radiocarbon dating of active faulting in the Agri High Valley, Southern Italy, J. Geodyn., 29, 371-386.

Giordano, G., D. De Rita, R. CAS and S. Rodani (2002): Valley pound and ignimbrite veneer deposits in the small volume phreatomagmatic «Peperino Albano» basic ignimbrite, Lago Albano maar, Colli Albani volcano, Italy: influence of topography, J. Volcanol. Geotherm. Res., 118, 131-144.

Guest, J.E., A.M. Duncan and D.K. Chester (1988): Monte Vulture Volcano (Basilicata, Italy): an analysis of morphology and volcanoclastic facies, Bull. Volcanol., 50, 244-257.

Hippolyte, J.C., J. Angelier and F. Roure (1994): A major geodynamic change revealed by Quaternary stress patterns in the Southern Apennines (Italy), Tectonophysics, 230, 199-210.

Hippolyte, J.C., J. ANGElier and E. BARRIER (1995): Compressional and extensional tectonics in an arc system: example of the Southern Apennines, J. Struct. Geol., 17, 1725-1740.
Karner, D.B. and P.R. RenNe (1998): ${ }^{40} \mathrm{Ar} /{ }^{39} \mathrm{Ar}$ geochronology of Roman Volcanic Province tephra in the Tiber River Valley: age calibration of middle Pleistocene sealevel changes, Geol. Soc. Am. Bull., 110, 740-747.

Karner, D.B., E. Juvigne, L. Brancaccio, A. Cinque, E. Russo Ermolli, N. Santangelo, S. Bernasconi and L. LIRER (1999): A potential early middle Pleistocene tephrostratotype for the Mediterranean Basin: the Vallo di Diano, Campania, Italy, Global Planetary Change, 21, 1-15.

Keller, J., W.B.F. Ryan, D. Ninkovich and R. AltherR (1978): Explosive volcanic activity in the Mediterranean over the past 200000 years as recorded in deepsea sediments, Geol. Soc. Am. Bull., 89, 591-604.

Laurenzi, M.A., D.I. Brocchini, C. Principe and G. FerRARA (1993): Mt. Vulture volcano chronostratigraphy and the effectiveness of dating young phlogopites, in EUG VII, Strasburg, 572-573 (abstracts).

La Volpe, L., D. Patella, L. Rapisardi and A. Tramacere (1984): The evolution of Monte Vulture volcano Southern Italy: inferences from volcanological, geological and deep dipole electrical sounding data, J. Volcanol. Geotherm. Res., 22, 147-162.

LuHR, J.F. and B. GiannetTI (1987): The brown leucitic tuff of the Roccamonfina volcano (Roman region, Italy), Contrib. Mineral. Petrol., 95, 420-436.

MaLinVERno, A. and W.B.F. RYAN (1986): Extension in the Tyrrhenian sea and shortening in the Apennines as a result of arc migration driven by sinking of the lithosphere, Tectonics, 5, 227-245.

Maschio, L., L. Ferranti and P. Burrato (2005): Active extension in the Val d'Agri area, Southern Apennines, Italy: implications for the geometry of the seismogenic belt, Geophys. J. Int. doi: 10.1111/j.1365-246X.2005.02597.x.

Melluso, L., V. Morra, A. Perrotta, C. Scarpati and M. AdABbo (1995): The eruption of the Breccia Museo (Campi Flegrei, Italy): fractional crystallization processes in a shallow, zoned magma chamber and implications for the eruptive dynamics, J. Volcanol. Geotherm. Res., 68, 325-339.

Melluso, L., V. Morra and P. Di Girolamo (1996): The Mt. Vulture volcanic complex (Italy): evidence for distinct parental magmas and for residual melts with melilite, Mineral. Petrol., 56, 225-250.

NARCisi, B. and L. Vezzoli (1999): Quaternary stratigraphy of distal tephra layers in the Mediterranean - An overview, Global Planetary Change, 21, 31-50.

Pappalardo, L., M. Piochi, M. D'Antonio, L. CivetTa and R. Petrini (2002): Evidence for multi-stage magmatic evolution during the past $60 \mathrm{kyr}$ at Campi Flegrei (Italy) deduced from $\mathrm{Sr}, \mathrm{Nd}$ and $\mathrm{Pb}$ isotope data, $J$. Petrol., 8, 1415-1434.

Paterne, M., F. Guichard, J. Labeyrie, P.Y. Gillot and J.C. DuPLESSY (1986): Tyrrhenian Sea tephrochronology of the oxygen isotope record for the past 60000 years, Mar. Geol., 72, 259-285.

Paterne, M., F Guichard and J. Labeyrie (1988): Explosive activity of the south Italian volcanoes during the past 80000 years as determined by marine tephrochronology, J. Vocanol. Geotherm. Res., 34, 153-172.

Poli, S., S. Chiesa, P.Y. Gillot, A. GREgnanin and F. GUICHARD (1987): Chemistry versus time in the volcanic complex of Ischia (Gulf of Naples, Italy): evi- 
dence of successive magmatic cycles, Contrib. Mineral. Petrol., 95, 322-335.

Renne, P.R., K. Deckart, M. Ernesto, G. Féraud and E.M. Piccirillo (1996): Age of the Ponta Grossa Dike Swarm (Brazil) and implications for Paraná flood volcanism, Earth Planet. Sc. Lett., 144 (1-2), 199-211.

Renne, P.R., C.C. Swisher, A.L. Deino, D.B. Karner, T. Owens and D.J. De PAOLo (1998): Intercalibration of standards, absolute ages and uncertainties in ${ }^{40} \mathrm{Ar} /{ }^{39} \mathrm{Ar}$ dating, Chem. Geol., 145 (1-2), 117-152.

Roland, G., F. Bellucci, M.T. HeIZler, H.E. Belkin and B. De Vivo (2003): Tectonic controls on the genesis of ignimbrites from Campanian Volcanic Zone, Southern Italy, Mineral. Petrol., 79, 3-31.

Rosi, M. and A. Sbrana (1983): Phlegrean Fields, CNR Quad. Ric. Sci., 114 (9), pp. 176.

Santacroce, R. (1987): Somma-Vesuvius, Quad. Ric. Sci., 114 (8), pp. 243.

Stoppa, F. and C. Principe (1997): Eruption style and petrology of a new carbonatitic suite from the Mt. Vulture Southern Italy: the Monticchio Lakes Formation, J. Volcanol. Geotherm. Res., 78, 251-265.

Stoppa, F. and A.R. Woolley (1997): The Italian carbon- atites: field occurrence, petrology and regional significance, Mineral. Petrol., 59, 43-67.

Tetley, N., I. Mc Dougall and H.R. Heydegger (1980): Thermal neutron interferences in the ${ }^{40} \mathrm{Ar} /{ }^{39} \mathrm{Ar}$ dating technique, J. Geophys. Res., 85, 7201-7205.

WASHINGTON, H.S. (1906): The Roman comagmatic region, Carnegie Inst. Washington, 57, pp. 199.

Winchester, J.H. and P.A. Floyd (1977): Geochemical discrimination of different magma series and their differentiation products using immobile elements, Chem. Geol., 20, 325-343.

WorkING GROuP CPTI (1999): Catalogo Parametrico dei Terremoti Italiani, Versione 2004 (CPTI04) (INGV, Bologna), (available on line at http://emidius.mi.ingv.it/ CPTI04/).

Wulf, S., M. Kraml, A. Brauer, J. Keller and J.F.W. NeGENDANK (2004): Tephrochronology of the $100 \mathrm{ka}$ lacustrine sediment record of Lago Grande di Monticchio (Southern Italy), Quat. Int., 122, 7-30.

(received January 18, 2006; accepted October 13, 2006) 